\title{
Performed Substance Administration Treatment Vehicle Volume
}

National Cancer Institute

\section{Source}

National Cancer Institute. Performed Substance Administration Treatment Vehicle

Volume. NCI Thesaurus. Code C93980.

The quantity and units of treatment vehicle used. 